\title{
LECTOTYPIFICATION OF TORREY'S SPECIES OF SCHAUERIA (ACANTHACEAE)
}

\author{
Thomas F. Daniel ${ }^{1}$
}

\section{Summary}

Two species of Schaueria now recognized in the genus Carlowrightia, $S$. linearifolia Torrey and $S$. parvifolia Torrey, are based on mixed collections. They are lectotypified here for the first time.

Lectotypification of the two species of Schaueria described by John Torrey in his Botany of the Boundary is essential to the application of names in Carlowrightia A. Gray, into which $S$. linearifolia and $S$. parvifolia have been transferred, because in the protologue of each, Torrey cited collections including more than one species. Lectotypification is complicated by the former practice of mounting several collections on a single herbarium sheet without clear correlation of the specimens and their accompanying labels and by the varied handwriting styles of Torrey.

The botanists of the Mexican Boundary Survey of 1849-1852 (under the commissionership of Major W. H. Emory) sent most of their collections to recognized botanical centers for identification and distribution. The specimens collected by Charles Wright were sent to Asa Gray (except for Cactaceae, which went to Engelmann), while those of J. M. Bigelow, C. C. Parry, and A. C. Schott went directly to Torrey. For Wright's collections, Gray usually provided two types of printed, blue labels, one for the collections of 1849 (Fig. 1) and the other for the collections of 1851 and 1852 (Fig. 2). Some of the collections of 1852 bear labels similar to the latter type, but lack "1851." According to Dr. Elizabeth Shaw of the Gray Herbarium (pers. comm.), Gray often pencilled numbers on these labels, corresponding to the numbers used by Wright in his field lists which are now at Harvard University. A set of Wright's collections with the blue labels went to Torrey who included them in his report on the botany of the United States and Mexican Boundary Survey. The specimens which went directly to Torrey received a printed Mexican Boundary Survey label (Figs. 3 and 4).

The lectotypes are chosen from specimens in the Torrey Herbarium (now at NY) or other specimens bearing Torrey's handwriting. The variation in Torrey's handwriting is evident from the samples provided by Burdet (1978); however, his uppercase S's and T's and his symbol for "and" are usually distinctive. The inked writing on the four labels in Figures 1 through 4 is presumed to be that of Torrey.

Carlowrightia linearifolia (Torrey) Gray, Proc. Amer. Acad. Arts 13: 364. 1878. Not $C$. $l i$ nearifolia Lindau (1897).

Schaueria linearifolia Torrey, Bot. Bound. in W. H. Emory, Report on the United States and Mexican Boundary Survey 123. 1859. Type: "Collected in expedition from Western Texas to El Paso, New Mexico, May-October, 1849," Wright 436 (Lectotype: US!; isolectotypes: GH! 2 sheets, PH!, TEX!).

In the protologue of this species, Torrey provided the following specimen citations: "Rocks at the mouth of the Great cañon of the Rio Grande, and on the Burro

1 Department of Botany, University of Michigan, Ann Arbor, MI 48109, U.S.A. 


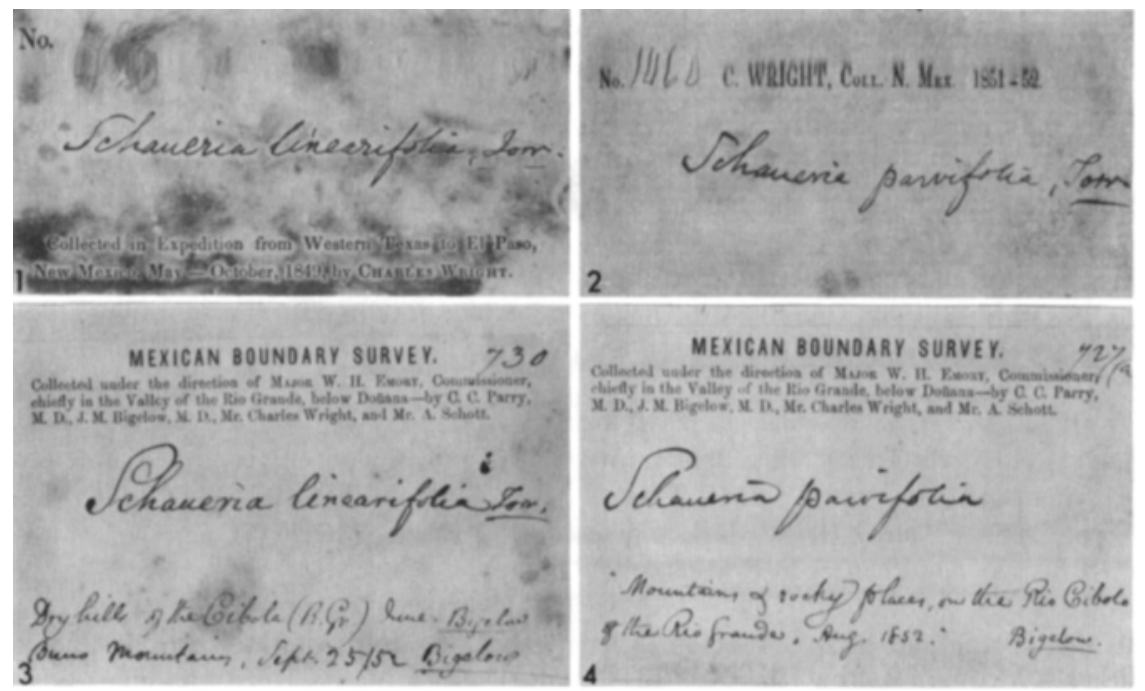

Figs. 14. Herbarium labels of collections from the United States and Mexican Boundary Survey. 1. Wright 436. 2. Wright 1460. 3. Mex. Bound. Surv. 730. 4. Mex. Bound. Surv. $727 a$.

mountains; June-October; Bigelow, Parry. (No. 436, Wright)." There are two sheets of $S$. linearifolia in the Torrey Herbarium at NY, both accompanied by Mexican Boundary Survey labels on which the number 730 has been written. One sheet contains a single plant of Justicia warnockii Turner and written on the label in Torrey's handwriting is "Schaueria linearifolia n. sp. Mouth of the Great Cañon of the Rio Grande. Bigelow." Attached to this speciman is a piece of paper bearing illustrations and fragments of a flower of what appears to be a species of Carlowrightia. On this slip of paper Torrey wrote " 'Camp Green Oct. 30 50' Parry." Duplicates of 730 at NY and US are mixed collections, containing both $C$. linearifolia and $J$. warnockii.

Although Torrey's description of the vegetative portions of $S$. linearifolia fits both $J$. warnockii and $C$. linearifolia equally well, his descriptions of the corolla (subbilabiate) and the anther locules (muticous) more closely fit $C$. linearifolia. In $J$. warnockii the corolla is strongly zygomorphic and the anther locules are spurred. The distinctions between these two species are discussed further by Daniel (1980). Although there are buds on the specimen of J. warnockii, Torrey's description of the flower must have been taken from the drawings and/or flowers of a species of Carlowrightia (presumably $C$. linearifolia supplied by Parry) attached to the specimen or other specimens.

The other sheet numbered 730 in the Torrey Herbarium contains at least two flowering collections of $C$. linearifolia. Written on the label (Fig. 3) in Torrey's handwriting is, "Schaueria linearifolia Torr." The collection data, also in Torrey's handwriting, are "Dry hills of the Cibolo (R. Gr.) June, Bigelow" and "Burro Mountains, Sept. 25/52 Bigelow." There is no indication as to which of the four specimens on the sheet corresponds to which locality.

The only other extant collection of this species cited by Torrey is Wright 436, which is not represented by a specimen in the Torrey Herbarium. The identification on Wright 436 at US (Fig. 1), however, is in Torrey's handwriting, indicating he saw this specimen. Because there is no ambiguity in the label data or the number of collections on the sheet, this specimen is chosen as the lectotype.

According to Dr. Shaw (pers. comm.), the parentheses around the collection number of Wright's specimen in Botany of the Boundary was used only as a typographical device to set the number apart from the rest of the text. Torrey repeated this 
procedure, albeit inconsistently, elsewhere in the text with the numbers of Wright and other collectors.

Although the type locality is not given precisely, Wooton (1906) and Geiser (1935) have shown that Wright's collections of 1849 probably all came from what is now the state of Texas. Using the number " 436 " pencilled on the label by Gray, which corresponds to the number used by Wright in his field notes, Dr. Shaw (pers. comm.) is able to determine that Wright's specimen was collected on 28 August 1849 between the Chispa Mountains (on the Culberson-Jeff Davis County line) and Lobo Siding (Culberson County) to the northwest, an area in which this species is common.

Carlowrightia torreyana Wasshausen, Phytologia 12: 427. 1965.

Schaueria parvifolia Torrey, Bot. Bound. in W. H. Emory, Report on the United States and Mexican Boundary Survey 122. 1859. Type: "Coll. N. Mex. 1851-52," Wright 1460 (Lectotype: NY ex Torrey Herb.!; isolectotypes: GH! 2 sheets, MO!, NY!, not Wright 1460 PH!). Not C. parvifolia T. S. Brandegee (1911).

In the protologue of this species, Torrey cited the following collections and localities: "Mountains and rocky places on the Cibolo of the Rio Grande; August; Bigelow. Monterey, Nuevo Leon; Dr. Edwards, Dr. Gregg. Howard Springs; Schott. (No. 1460, Wright. No. 1459 is an early state of the same, in which the flowering branches or spikes are not developed.) At Oak Creek, western Texas, Mr. Schott collected specimens with larger and almost orbicular obscurely repand leaves. They probably grew in a shady place." Five sheets bearing these collections and two others were in Torrey's herbarium.

Bigelow's collection from Cibolo Creek, accompanied by a Mexican Boundary Survey label on which " $727 a$ " has been written (Fig. 4), is mounted on the same sheet as a Wright specimen collected in 1849 ("433" has been written on the blue label and "727a, Camargo Gregg $=1460$ Wright $\& 433$ Wright" is written in several handwritings on drawings of the flower attached to the specimen) which proves to be Carlowrightia serpyllifolia Gray. Both specimens are annotated as $S$. parvifolia in Torrey's handwriting. The specimen of $C$. serpyllifolia, if not added to the sheet after publication of Torrey's treatment, may have been the source of his description of the species as being glandular pubescent. In $C$. torreyana glandular pubescence is restricted to the inflorescence axis, whereas in most specimens of $C$. serpyllifolia all vegetative portions of the plant are glandular. The specimen of $C$. serpyllifolia may also have been the source of Torrey's description of the corolla as purple. There are no indications of corolla color on the labels and although there are no corollas presently on the $C$. serpyllifolia specimen, there may have been at one time. In $C$. serpyllifolia the corolla is purple, whereas in $C$. torreyana the corrolla is white with purple veins on the upper lip. An equally likely explanation for the description of the corolla as purple, however, is the fact that the corollas of most of the whiteflowered species of Carlowrightia become dark, usually with a purplish tinge, after drying.

Edwards' specimen from Monterrey, consisting of four fragments as designated by numbers pencilled on the sheet, is mounted on the same sheet as Wright 1460. The former proves to be a mixture of $C$. torreyana and $C$. texana Henrickson \& Daniel, a species long confused with $C$. torreyana (Henrickson and Daniel, 1979). Wright 1460 on this sheet is C. torreyana.

Wright 1459 , thought by Torrey to be an early state of C. torreyana, is C. texana. Mounted on the same sheet as this specimen is Schott's collection $(=C$. torreyana $)$ from Howard Springs. Seeds glued to drawings of flowers, and labeled as "Howard Spring, Schott" are undoubtedly from Wright 1459 (=C. texana), not Schott's specimen of $C$. torreyana. The seeds of $C$. torreyana may be distinguished from those of $C$. texana by their dentate margins. In $C$. texana the seed margins are entire. In addition, capsules containing seeds are present on the Wright specimen, however, no fruits or seeds are present on the Schott specimen. 
Gregg's collection from Monterrey is mounted on the same sheet as a Riddell collection from Texas. One of the five specimens on the sheet is $C$. texana, the others all being $C$. torreyana. The entire sheet was annotated by Torrey as $S$. parvifolia, and there is no indication as to which specimens correspond to which label.

Schott's collection from Oak Creek is mounted on a sheet with a Mexican Boundary Survey label (on which "727b" and "S. parvifolia Torr." were written by Torrey) and what appears to be a field label (on which "Acanthaceae. Rio Bravo del Norte. Oak Creek. October 1852 Schott" is written). The three specimens on this sheet, which by their morphology and preservation appear to represent a single collection, are all $C$. torreyana. The collection is mentioned only incidentally in Torrey's protologue, however.

Wright 1460 (NY, ex Torrey Herb.) is chosen as the lectotype of $S$. parvifolia because it is an ample specimen which has been previously distinguished, by numbers, from Edwards' mixed collection of C. texana and C. torreyana. It is not known whether the specimens were numbered when the two collections were initially brought together or later in an attempt to correlate the specimens with the labels. The lectotype is the specimen on the right side of the sheet (no. 4) which is closest to Wright's label (Fig. 2).

None of the labels accompanying specimens of Wright 1460 contain one of Gray's pencilled numbers, thus the precise locality of this collection is not known. One of the specimens at GH, however, bears a blue label with " 1852 " as the only date. In 1851 and 1852, Wright collected in Texas, New Mexico, Arizona, Sonora, and Chihuahua (Wooton, 1906). Within this region, the species is known only from Texas, occurring from the Pecos River eastward across the Edwards Plateau to San Antonio and southward to Laredo. Wright appears to have been in the region between the Pecos River and San Antonio during the summer of 1852 (Wooton, 1906).

\section{Acknowledgments}

I am grateful for the suggestions and interpretations of Drs. E. G. Voss, W. R. Anderson, and R. McVaugh. Dr. E. Shaw kindly provided information concerning the collections of Charles Wright and D. Bay photographed the herbarium labels.

\section{References}

Burdet, H. M. 1978. Cartulae ad botanicorum graphicem. XIV. Candollea 33: 409-454.

Daniel, T. F. 1980. The genus Justicia (Acanthaceae) in the Chihuahuan Desert. Contr. Univ. Michigan Herb. 14: 61-67.

Geiser, S. W. 1935. Charles Wright's 1849 botanical collecting-trip from San Antonio to El Paso; with type-localities for new species. Field and Lab. 4: 23-32.

Henrickson, J., and T. F. Daniel. 1979. Three new species of Carlowrightia (Acanthaceae) from the Chihuahuan Desert Region. Madroño 26: 26-36.

Wooton, E. O. 1906. Southwestern localities visited by Charles Wright. Bull. Torrey Bot. Club 33: 561-566. 